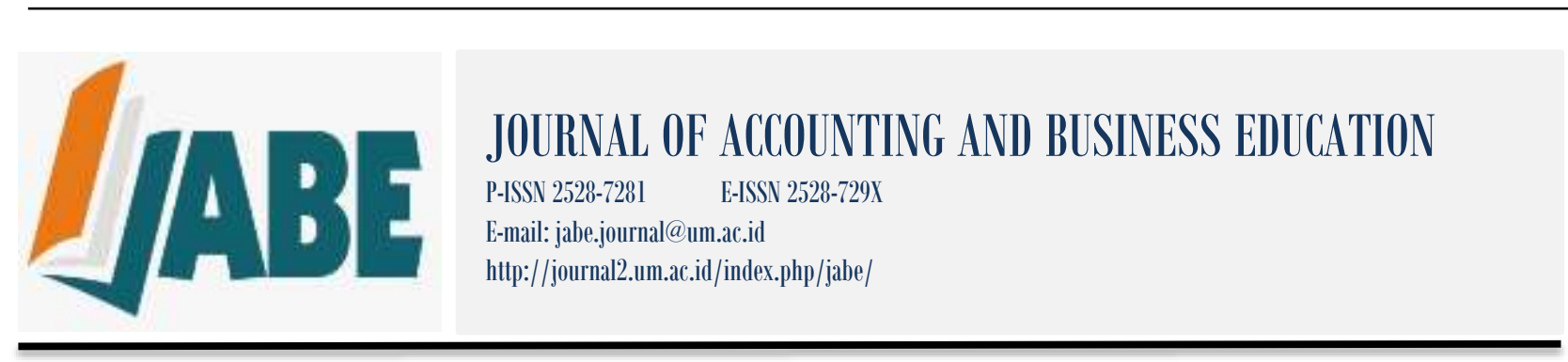

\title{
The Accountability of Business Entity with Sadaqah Concept in the Frame of Eling Sangkan Paraning Dumadi
}

\author{
Selfiah $^{1}$ \\ Iwan Triyuwono ${ }^{2}$ \\ Yeney Widya Prihatiningtyas ${ }^{3}$ \\ ${ }^{I}$ Accounting Department, Sekolah Tinggi Ilmu Ekonomi Asia, Indonesia \\ ${ }^{2}$ Accounting Department, Faculty of Economics and Business, Universitas Brawijaya, Indonesia \\ ${ }^{3}$ Accounting Department, Faculty of Economics and Business, Universitas Brawijaya, Indonesia \\ Email: selfiahasyim@gmail.com
}

DOI: http://dx.doi.org/10.26675/jabe.v6i1.9999

\begin{abstract}
This research aims at formulating the concept of accountability of business entity based on Islamic spiritual values. The Islamic-spiritualist methodology is greatly needed to promote this research's objective. The mutually integrated Physical Endeavor (IL) and Spiritual Endeavor (IB) were used to collect, reduce, analyze data and formulate the concept. Metaphor of Salah movements was used to analyze physical empirical data and spiritual empirical data. The research result shows that the accountability of business entity with sadaqah concept aims at trapping the stakeholders (humans) in spiritual consciousness by "maximizing sadaqah", representing the spiritual accountability of business entity management. The spiritual value of love internalized in the concept of spiritual accountability may stimulate other spiritual values (such as: itsar (altruism), volunteerism, willingness, righteousness, honesty, and justice values), thus it may promote the welfare of all stakeholders (God, human, and nature) through distribution of added material (monetary and non-monetary), psychological, and spiritual values. The result of this research may be taken as the base to build sharia accounting concept and theory. In addition, this research may also stimulate stakeholders' (human) behavior based on spiritual values, particularly spiritual value of love.
\end{abstract}

Article History

Received:

24 October 2019

Revised:

6 February 2021

Accepted:

25 February 2021

Keywords

Accountability, Islamic-

Spiritualist, Spiritual

Values, Metaphor of

Salah Movements

Citation: Selfiah, S., Triyuwono, I., Prihatiningtyas, Y, W. (2021). The Accountability of Business Entity with Sadaqah Concept in the Frame of Eling Sangkan Paraning Dumadi. Journal of Accounting and Business Education, 6 (1),61-74

\section{INTRODUCTION}

The sharia business entities developing in Indonesia are not yet fully based on tauhid (Oneness of God), that is to have godly values, from transcendent (base), permanent (concept), to immanent (practice). Islamic perspective is needed (Rahman, 1998; Rizk, 2008) as the foundation in organizing a sharia business entity. One of which is to shift the paradigm from conventional utilitarian economy to Islamic Economy (Presley \& Sessions, 1994; Zaman, 2009). Islam brings changes to all fields and forms civilization since it teaches three values (Sunanto, 2014), namely: (1) Islam teaches the existence of the afterlife which is associated with the worldly life; (2) Islam teaches its followers to be responsible for their 
own afterlife fate; (3) Islam teaches social and state life rules in the horizon of solidarity life of Muslim throughout the world.

Maximization of economic man's utilitarian, rational behaviors in Islamic economy is replaced by "homo-economicus-Islamicus" (Al-Zarqa, 1980) of which consumer's behaviors are restricted by "moral filter" and redefines self-interest extending to the afterlife interest (Chapra, 1992). However, it is as if Homo Economicus Islamicus Islamizes homo economicus, thus the emphasis on worldly element is still dominant. In researches on Islamic economy, the human self-concept in Islamic perspective is popularly known as Homo Islamicus (Farooq, 2011; Zaman, 2009). Homo Islamicus is regarded as the ideal human self-concept, that is human with Islamic spirit and committed to Islamic values. This means that using Islamic perspective, human behavior as "homo Islamicus" will have more complete orientation, namely worldly and afterlife orientation (Rafiki \& Wahab, 2014) which is in line with the "Coupling Epistemology" (Triyuwono, 2015).

Further, there is Homo Spiritus (Triyuwono, 2015) with strong religious and spiritual belief characteristics in transcendental relationship with God, human and nature. Homo Spiritus has more universal view. Spiritual training is an important method in forming Homo Spiritus's characteristics, focusing on four elements, namely passion, mind, heart and soul. The highest achievement of Homo Spiritus is spiritual man at the pinnacle of God consciousness (Triyuwono, 2015).

Business entity is one of the mediums for human to worship Allah. This is based on a thinking that humans essentially exist on earth to worship (devotion to) Allah (Hassan, 1982). Worshipping Allah may be performed in two ways, namely maghdah worship and good deeds and acts. Business entity is not a partial reality, but a unity of realities covering human reality, material reality, system reality, and certainly Absolute Reality (Allah).

Human reality is to serve as khalifah with the right to manage material reality and system reality as mandated by Allah. Human as Allah's representative on earth is assigned to work hard and build the world and use its natural resources to the best way as set forth by God (Ibrahim, S. H. M., \& Yaya, 2005). According to Triyuwono (2015), the Sharia Enterprise Theory (SET) may internalize Islamic values through the concept of zakat implemented in the distribution of wealth and value-added to the stakeholders. Triyuwono (2015) more specifically divides stakeholders in the concept of SET into: (1) direct stakeholders, including: owner, management, government employee, supplier, customer, and others; and (2) indirect stakeholders, including: mustahiq society (beneficiary zakat, infaq, sadaqah) and natural environment. This shows that the accountability of business entity desired by SET is not only to human (Shearer, 2002), but also to natural environment and Allah.

Researches on spirituality based accounting have been conducted, such as ones by (Triyuwono, 2016) on the holistic concept of managerial performance and by Hidayah et al., (2019) on the role of accounting in interpreting the application of the Islamic Financial Institutions (IFI) to settle the struggle taking place in the implementation of PLS scheme as an alternative medium of spirituality based finance. Other researches associating organization with spirituality include Garcia-Zamor (2003) and Mitroff and Denton (1999), but they tend to be concerning the influence of spirituality practice on organizational performance. There are only few researches on the concept of business entity with spiritual environment from human consciousness, objective, management, accountability to instrument used. Most of the researches focus on Islamic financial institution and nonprofit Islamic organization (Kamaluddin et al., 2018; Asdar et al., 2014; Randa et al., 2011; Suhaimi Nahar \& Yaacob, 2011; Riyanti \& Irianto, 2011). That there are limited researches on spirituality based accounting is a challenge for researchers to formulate the concept of accountability of spirituality based business entity.

This research aims at formulating the concept of accountability of business entity based on Islamic spiritual values using Metaphor of Salah Movements (MGS) as the analysis instrument. Amernic \& Craig (2009) propose association of metaphor with accounting, which has been widely used to illustrate the essence of accounting. This MGS analysis will trap the researcher as the homo spiritus Islamicus framed in the Eling Sangkan Paraning Dumadi (ESPD) consciousness. ESPD is a Javanese philosophy rooting from Islamic spirituality which may bring humans to God consciousness. Homo spiritus Islamicus considers business entity as part of spiritual reality of which essence is relative. Therefore, the concept of 
accountability this research produces will be holistic, which is the accountability to God, human and nature, both in material and immaterial forms.

\section{LITERATURE REVIEW AND HYPOTHESES}

Accountability is an underlying concept of an organization, and is even the main factor to cause the fall of some giant companies in the world, such as accounting office Arthur Andersen in Enron and WorldCom because of accountability failure (Frink and Klimoski, 2004). Accountability in the concept of modern entity (entity theory) has not touched the level to stimulate God consciousness, but tends to prioritize mind rationality. This may be observed from the definition by Roberts and Scapens (1985), that accountability is a relationship between the giver, beneficiary and other party regarding something acceptable to common sense. The said relationship is the logical consequence between the agent (management) and the principal (owner) see (Triyuwono and Roekhudin, 2000; Frink and Klimoski, 2004). Accountability can no longer be charged as the obligation to account for success or failure of organization's mission implementation in reaching the designated aims and goals (Stanbury, 2003). The definition of accountability above may cause its own pressure to the implementer.

The concept of accountability is influenced by the view on human. For example, the concept of accountability of the Entity Theory, which prioritizes accountability to capital owner (shareholder) and is oriented only to something material (maximum profit). This is caused by the dominance of homo economicus view with utilitarian rational behavior, thus the accountability of business entity of the Entity Theory is egoistic and materialistic (Triyuwono, 2006). This is different from the concept of accountability of business entity based on Sharia Enterprise Theory (SET), which is oriented to zakat. The self-view of Homo Islamicus see (Zaman, 2009; Farooq, 2011) has more complete orientation, namely worldly and afterlife views, in line with the "Coupling Epistemology" (Triyuwono, 2015) which influences the concept of SET. Therefore, accountability according to SET is not only made to capital owner, but also to God, human, and universe.

The emergence of Homo Spiritus (Triyuwono, 2015) with strong religious and spiritual belief characteristics, in the transcendental relationship with God, human and nature, is expected to shift the view of Homo Islamicus which is minimal in spiritual values. This is also reflected in the meaning of sharia that, according to the opinion of Syekh al-Azhar, Mahmoud Syaltout, is the codes created by Allah for humans to take guidelines from in arranging their relationship with God, with humans, both Muslim and Non-Muslim, nature and all living beings (Bakri, 1996). Homo Spiritus has four elements, namely passion, mind, heart and soul, and more universal view, as reflected in homo spiritus's behaviors which are laden with spiritual values. Islamic teaching itself, according to Khan (2010), is the way of live, which means that humans need Islamic spiritual values (universal) in living the life. Therefore, the concept of accountability which is laden with spiritual values is needed as the base of theory and practice of sharia accounting. Internalization of spiritual values of the operational instruments of business entity may transform into how to behave (ethics) and its use in decision making which is laden with virtue values.

\section{METHODS}

The paradigm of Islamic spiritualist as the umbrella of this research has Tauhid as its foundation and aims at stimulating God consciousness. Eling Sangkan Paraning Dumadi (ESPD) which frames this research roots from a Javanese philosophy which is laden with Islamic spiritual values. This philosophy is a depiction of human with God consciousness, which is to take Allah as the focus of all life activities. It is from Allah and to return to Him (inna lillahi wa inna ilaihi raji'un). Eling Sangkan Paraning Dumadi is a wise expression in Javanese life. Eling in Indonesian language bears the meaning of remembering, conscious, or regaining consciousness.

The spiritual essence of 'Eling' is spiritual consciousness which brings humans to an understanding of self-condition that is derived from (sangkan) and going to where the course of life is heading to (paraning dumadi). In the concept of heavenly religion, the condition 'eling' becomes bidayah (opener) of the presence of God's hidayah (grace). Al-Qur'an even repeatedly states 'udzukuru', 'O you remember', 
'remember when', 'remember that' and others. This is in line with the opinion of Chodjim (2003) regarding dzikr, which means memory, something to remember.

The use of "ESPD" as the frame of this research aims at confining the researcher's spiritual view. The Physical Endeavor (IL) and Spiritual Endeavor (IB) methods were used in data collection, reduction and analysis and concept formulation. IL method is any of the best attempts in involvement of researcher's physique (dhahir) in all activities in the form of physical and mind sensing, while IB is any of the best spiritual attempts in involvement of researcher's spirit (holy soul) in the form of spiritual activities. The data used in the research included empirical-physical data and empirical-spiritual data. The empiricalphysical data were obtained, for example, through a case study with PT. Karim Barokah Jaya, located in Jakarta. Case study, as stated by Creswell (2016), is a qualitative strategy where the researcher studies a program, occurrence, activity, process, or one or more individuals more thoroughly, thus the researcher must collect detailed information using various data collecting procedures within a certain period of time.

The analysis instrument of Metaphor of Salah Movements (MGS) employed in this research was also generated from the IL and IB methods. This MGS analysis was obtained through a Zikir, Doa (Prayer) and Tafakur (ZDT) procedure (Triyuwono, 2015). MGS covered four core movements in Salah (ritual) activity. First, standing reflects vertical relationship, which is human's relationship with God. Second, rukuk (bowing) reflects horizontal relationship, which is relationship between humans, other living beings and the universe. Third, prostration reflects the destination, that is Allah as the main destination. Fourth, sitting reflects distribution of welfare to all creatures throughout the universe.

The phrase "lillahi ta'ala" in Salah intention brings human's commitment to Allah. The manifestation of intention (commitment) is implied in the phrase "Allahu Akbar", implying the meaning that all human's life activities are conducted in devotion to (worshipping) Allah only (Muhyiddin and Salahuddin, 2006). The movement of raising two hands in takbiratul ihram reflects power and limitation. It is the standing movement which is later used to analyze the empirical-physical and empirical-spiritual data to produce the concept of accountability of business entity with sadaqah concept in the frame of "ESPD".

This methodology may stimulate and maximize the researcher's potential by integrating the performance of rational mind (physical) with spirituality (spiritual), thus the researcher is able to think contemplatively, holistically, dialectically, imaginatively, creatively, rationally and radically see (Triyuwono, et al., 2016). This methodology implementation also serves as the media to internalize the ultimate spiritual values such as love, justice, honesty, honor, responsibility and patience (Agustian, 2001) in each instrument produced. Consequently, the scientific knowledge produced by the researcher will be laden with spiritual values, and able to stimulate its user's God consciousness.

\section{RESULTS AND DISCUSSION}

As the meaning of "ESPD" explained above, the stakeholders (humans) will deem that the existence of business entity is the form of human's commitment to Allah. Human's commitment to Allah is basically to perform all of His instructions and avoid all of His prohibitions. In the context of business entity, the owner, management, and employee cooperate with each other to implement the commitment to managing and running business operation pursuant to what Allah has designated. Human's commitment to Allah will have the implication for human's perspective of power and limitation.

\section{Business Entity is Stakeholders' Commitment to Allah}

Standing in salah reflects the vertical relationship between human and God. This may be reciprocal relationship, in the form of Allah's instruction for human and otherwise human's obligation to obey, submit to and comply with Allah's instruction. Human's relationship with God is often associated with worship. Worship as the manifestation of a servant's devotion is not limited to ritual worship, but all muamalah activities performed by humans intended to be for the sake of Allah and pursuant to the Islamic law are also included in worship.

The phrase "lillahi ta'ala" in Salah intention brings human to be committed to Allah. Human's commitment to Allah is their base of commitment to other humans, other living beings, and the nature. 
Humans' commitment to Allah is to submit to and comply with Allah's laws which are contained in AlQur'an and Hadith. Human's commitment to Allah may be implemented individually or in group.

One of the manifestations of implementation of human's individual commitment to Allah is Salah ritual. Business entity as a reality which is inseparable from the Absolute Reality should give each individual with space and time to worship. PT. KBJ also has such commitment, as said by Mr. HH:

"Congregational Salah is indeed performed daily at working hours, and there is annual Prophet's Birthday commemoration, as well as annual Salah tarawih by reciting Al-Qur'an until the end."

The phrase "congregational Salah" which is performed "during working hours" shows that PT. KBJ gives anyone the freedom of worship. In Islamic teaching, congregational Salah is deemed far better than individual Salah. The habitual congregational Salah at PT. KBJ is the commitment of Muslim's individual consciousness to Allah. The Salah ritual activity is expected to reflect the spiritual values in human behavior in operating their business entity and in other activities.

In addition, the congregational Salah ritual activity at PT. KBJ positively influences the psychology (mental) of individuals involved in it. The reflection of Salah ritual at workplace may give the spirit as reflected in increased enthusiasm (zeal) to work and give the best to the company voluntarily (wholeheartedly). This working enthusiasm (zeal) is categorized as mental intelligence by Agustian (2001), while Triyuwono (2006) calls it mental piety. Further, sense of volunteerism (wholeheartedness) is called by Agustian (2001) as spiritual intelligence and Triyuwono (2006) prefer to use the term spiritual piety.

Currently, internalization of spiritual values into instrument used in implementing company's operational activity is quite important. This is justified by $\mathrm{Mr}$. $\mathrm{HH}$ in his other statement:

"Instilling religious values since early, such as through congregational Salah, and there are also commemorations such as Prophet's Birthday commemoration. Thus, it more or less instills the spiritual values, and it is proven to be beneficial. There was, in that environment, sorry to say... drugs... quite messy... Alhamdulillah... right now, those with good intention remain here, while those with bad intention against Allah SWT are all revealed and they quit."

Human's commitment to Allah is manifested in human's commitment to humans, other living beings and the nature. Commitment is not only in oral/verbal or written/textual form, but the true heart commitment has more power. When commitment to Allah is violated, commitment to humans will be worse. A good commitment to God, humans and natural environment is quite important in a relationship, as indicated in the interview with Mr. HH below:

"We perform Islamic law in sale and purchase contract, there must be agreement between two parties. In the early fruit season we make an offer to buyer, I have the items and goods this...this...this... the price is this...this...this... provided minimum order of..., it is said clearly. The packaging is like this per packing, with this size, we explain it all. The price is this. And we just wait for them to agree, when they have agreed, it is consensual."

Mr. HH's oral expression "perform Islamic law" explicitly indicates there is business entity owner's commitment in the form of compliance with implementation of sale and purchase transaction pursuant to Allah's rules (Islamic law). Besides commitment to Allah, commitment to humans is also important, which in the context of statement above is the commitment to buyer. This commitment may be implicitly identified in the informant's statement in the sale and purchase transaction made, through the expressions "there is agreement", "we explain it all", "agree", and "consensual". It is apparent that informant's spiritual consciousness is the driving motor to implement the values of virtue in decision making.

Mr. HH's other expression confirms that commitment is important as the manifestation of accountability, as follows:

"...The price is this. We just wait for them to agree, when they have agreed, it is consensual. And in case of fluctuating price, there must be prior notice. That is the business ethics... Thus, we cannot for them arbitrarily, the price increases... When we have offered them, for example, four Dollars per $\mathrm{kg}$, but suddenly it increases to four Dollars and twenty cents, that is our risk, since we are bound by the contract to the buyer this week, it must be four Dollars. And... when that is the case, next time we tell them, for next week, it is four point twenty, four Dollars and twenty cents, do you agree? When they agree, we can 
proceed... since the price increases, we just announce it. Fruits and vegetables have no stable price. Its price is high in early season, but in the peak season, the price falls, and a moment before the end of season, it increases again. When the price decreases, we consequently decreases the price. This is a business of trust."

The informant's explicit expression ("we are bound by the contract" and "consequent") and implicit expression ("there is prior notice" and "cannot force them arbitrarily") reflect the informant's mental piety and spiritual piety in keeping the commitment.

The expressions are the indicator of Mr. HH's commitment to their agreement with buyer. The said commitment is that Mr. HH will not... The commitment is also the manifestation of commitment to Allah. The other form of commitment of PT. KBJ may be found in Mr. HH's statement below:

"I once received an order for Bintang beer..., wild boar meat... but I rejected them. I said this is prohibited. This requires a special license for alcoholic drink and I don't have the license for it, I just provide general, fresh fruit, fresh vegetables, and... I don't want to violate Islamic law since there is no blessing in it. And lastly, He also required, he wanted one container of twenty feet, it was about ten tons, one requested item of which was Bintang beer, but I did not do it. I could prepare any other things, but not Bintang beer. But Mr. HH, it is difficult to sell them without Bintang beer (Mr. HH imitates potential buyer's answer in Indonesian language). I'm sorry... I cannot do it, although the profit was clearly high... but I was not hesitant to reject it."

The expressions "I rejected it", "I don't want to violate Islamic law", and "I'm sorry... I cannot do it", are the commitment not to violate Allah's law.

In addition, PT. KBJ also does tazkiyah over its property through zakat, infaq, sadaqah. Tazkiyah over property may cleanse the heart of the giver and the beneficiary from stinginess and may suppress materialistic view, thus suppressing love for property (material), and stimulate love for Allah. This may be observed in PT. KBJ's financial statement below:

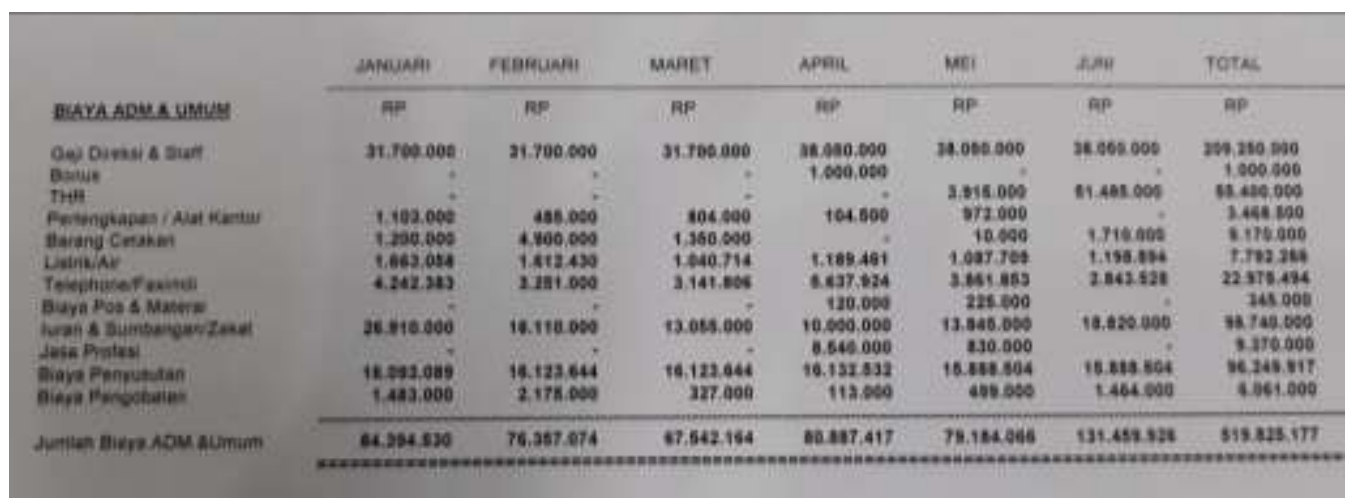

Figure 3. Part of PT. KBJ's Loss and Profit Statement Format

Based on the figure above, there is an account "Contribution \& Donation/Zakat". According to Mr. $\mathrm{HH}$, this account collects transactions of donation for orphans, infaq for mosque construction, income zakat, zakat maal (for property), sadaqah and other social expenses. The account "Contribution \& Donation/Zakat" serves as the owner and management's commitment to Allah, thus the account exists based on volunteerism. The account "Contribution \& Donation/Zakat" in the PT. KBJ's financial statement is categorized by Triyuwono (2006) as financial piety.

Further, my attention was drawn to one of the transactions in the "Contribution \& Donation/Zakat", namely sadaqah. I used IB method (through ZDT procedure) for the meaning of sadaqah and searched for the Islamic values of the concept of sadaqah . The meaning I obtained was a grant, either material or immaterial, which is based on volunteerism, righteousness, willingness, honesty, and justice.

Commitment is a bond arising from an agreement between two parties. Business entity is the medium to manifest human's commitment to Allah and human's commitment to humans, other living beings and the nature. The commitment is derived from the values of virtue emanated from spiritual consciousness. Business entity is a commitment given by Allah to owner, management, and employees, 
thus when the business entity is at the owner's hand, the owner together with the management and employees have commitment to Allah to manage and utilize it as per Allah's will.

\section{View of Stockholder's Power in Business Entity}

When "Allahu Akbar" is recited and appreciated thoroughly with the heart while raising both hands, it is this time when humans acknowledge that all powers belong only to Allah. Allah's absolute power cannot be repressed by humans, although they have planned anything perfectly, just like the occurrence to PT. KBJ as revealed through Mr. HH's statement below:

"In business, because of involvement of other people, in this case customers, I am demanded to be highly disciplined. Eventually, I turn to be like them, rigid... yes for yes... no for no..."

"Thus it should be decisive, it must be decisive against others. Alhamdulillah I am trusted. Even there is one person that is not willing to be served by others, just wanted me, since I understand that buyer's characters, thus yes for yes... no for no... like that... certainty is needed. "

"Except in case of unexpected matters, delayed flight, we just notice them that it is not our fault. I once sent items to Riyadh, but was stuck. Riyadh required 3 deliveries weekly, while the Saudi Arabian Airline only had direct Jakarta-Riyadh twice weekly, so how to meet the order? Principally, we must be capable of maximally serve customer's request. I agreed the 3 deliveries through an alternative, with a connecting flight, and I finally used Qatar. It was smooth initially, but in the middle... it was stuck in Doha, the fruits were suspended up to 11 days, and just dispatched. Destroyed..."

The expression "certainty is needed" implies that humans always desire perfection in anything. But there is Allah's power, which is implied through "unexpected matters". And Allah has the power to determine an occurrence not to in harmony with what humans desire, which is represented by "destroyed" in the interview.

The other power of Allah with PT. KBJ is revealed through Mr. HH's story of early establishment of PT. KBJ below:

"It was established in nineteen ninety one with a name of PT. AUJ initially, then... operated in export of vegetables, fresh fruits, and dried food stuffs, such as: crackers, brown sugar, candlenut, and other crops. Later... from nineteen ninety one to two thousand and ten, it was under the flag of PT. AUJ, and changed to PT. KBJ until now."

For a company to have been operating for twenty six years from "nineteen ninety one" (1991) until "now" (2017), it is not an ordinary journey. This reminds me of a company named Enron in the United States which operated for fifteen years (1986-2001) (Tonge et al., 2003). I wonder why PT. KBJ survives for twenty six years. Its survival must be under Allah's power and willing.

The occurrences with PT. KBJ above show the existence of Allah's power and confirm that humans are weak and lack of power. This lack of human's power is the reflection of movement of raising two hands in takbiratul ikhram in the "standing" movement in Salah, since all powers belong only to Allah (Ibn Arabi, t.t.).

Business entity is authorized to owner under Allah's power. I remember Mr. HH's statement as follows: "Allah's hands cover anything". This shows that although business entity is in owner's power, but owner's awareness is necessary that there is greater power than that he has, that is Allah's power.

\section{Limitation of Stakeholders' Power in Business Entity}

Standing in salah also reflects human's limited power. This limitation is implied in the two hands' position in takbiratul ihram which is in line with senses and mind. The said limitation is spiritual values, since spiritual values are the ultimate value (Agustian, 2001) which may create comfort, peace, and happiness for all people throughout the universe. Therefore, in implementing commitment and using their power, humans are limited by God's laws which are reflected in spiritual values.

Business entity in its operation needs limitations of human's power, since actually all powers belong only to Allah. The said limitations are spiritual values which are internalized in the instrument used by business entity. The power of modern business entity modern is in shareholders' egoistic value 
(Triyuwono, 2016). Shareholders' unlimited power directs to the use of company's operational instruments while disregarding mental and spiritual values.
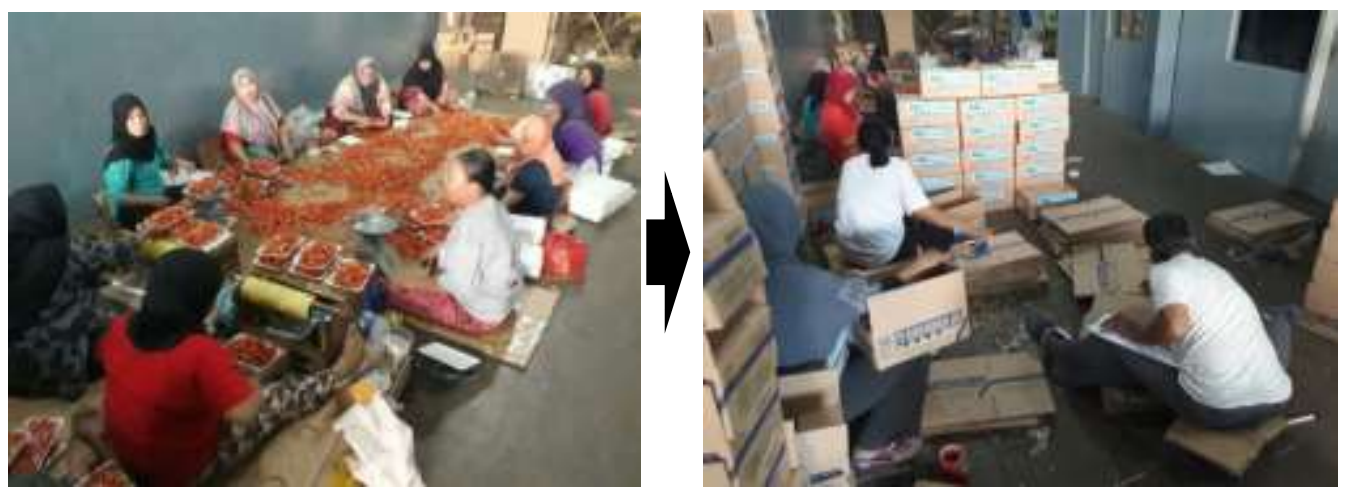

Figure 4. Packing and Sorting Processes at PT. KBJ's Warehouse

In figure 4 above, the sorting and packing processes are performed simply with human hands. It is far from the impression of sophisticate technology, which is full of machines with only some operators working following machine instruction without pause in pursuing target quantity.

The simplicity of the working system of sortation and packing divisions at PT. KBJ is one of the instruments chosen by the management which is limited by love value. Love is the characteristic of soul. The said soul is the core of spiritual heart, which may be called the deepest mental consciousness (Nurbakhsy, 2008). The essence of love is love for Allah, since human's love for creature and the universe is the manifestation of their love for Allah.

Love as depicted above will lead to a humanistic system, since the management will have the characteristic of prioritizing others (itsar). This has the implication of calm and comfortable working atmosphere, as may be observed in the attitude of employees of PT. KBJ while working, that they just sit with legs outstretched, occasionally talking and joking, and sometimes they also eat snacks and drink. The simplicity of the working system does not reduce the quality of deliverables, since in Mr. HH's opinion, they work heartily.

The working atmosphere in the warehouse of PT. KBJ above is quite contradictory to the working atmosphere in a company with sophisticated instruments. This may be observed from the depiction of Mr. HH's experience when he was working in a foreign-owned company. Below is Mr. HH's story of the working atmosphere at the foreign-owned company:

"Before joining PT. KBJ, I once, on a whim... applied to PT. PI, a big company. At that time, I applied for supervisor of its production division. Two supervisors supervised five thousand employees. Among the employment contract provisions, there are words which were quite a pressure, thus the words were emphasized: "willing to work twenty four hours nonstop", the words existed. It was indeed a foreign-owned company."

The English expression "pressure" which means putting pressure is an illustration of the mood felt by $\mathrm{Mr}$. HH when reading the employment contract where he applied for the job at that time. Mr. HH felt pressured by the clause of the employment contract "willing to work twenty four hours nonstop".

The illustration through Mr. HH's expression above may be taken that the policy made over the company owner and management's power is unlimited, while there should be limitation by the value of love for God as manifested in the love for humans and the nature. The clause "willing to work twenty four hours nonstop" implies that humans are deemed to be equal to inanimate object (machine) which is heartless and unable to feel human traits.

The human's unlimited power is caused by the shackle of nafs which is always material oriented (Nurbakhsy, 2008). Mr. HH's story below is still related to the story above: 
"For an Indonesian company, for example... requires twenty five employees of administrative section, a foreign company requires only ten, thus the employees are spurred to meet the target. They are paid high, but that's it... Let's say, mmm... when here, shop employees can sit that there are seats and are paid for five thousand hundred, but in this case the shop employees are given with one million but the seats are taken away. Thus there is no seat for the employees, they are just standing during working hours, that is foreigner (it means foreign-owned company) it is like that averagely... heavily exploited... and he is consequent during working hours. He is consequent to the work, but there is no tolerance in working, conversation, smoking cigarette is a no. That is foreigner."

The phrase "to meet the target" directs to an objective which is material oriented, thus there is no limitation of human value in the company owner and management's power. The word "consequent" in "he is consequent to the work" is related to "to meet the target". That is a causal relationship, which is the consequence of no tolerance because of company's material-oriented target.

Human's behaviors with "ESPD" consciousness are reflected by the metaphor of Salah movements, namely standing, rukuk (bowing), prostration, and sitting. Humans in "ESPD" consciousness show humans' vertical relationship (standing) with God as well as human's horizontal relationship (rukuk/bowing) with humans, other living beings and the universe. Humans with "ESPD" consciousness place Allah as the destination (prostration) that may lead humans to spread welfare (sitting) to all people throughout the universe.

Business entity as human's medium of Allah's giving, which is managed by adhering Allah's provisions, will generate profit which is acquiesced and blessed by Allah. Therefore, the existence of business entity is unavoidable in the relationship with Allah. The vertical line symbolized in salah's standing shows there is relationship of creatures and the universe with the Creator. This relationship will cause some consequence of the commitment between creatures and The Creator. Commitment to Allah's provisions is the manifestation of human's accountability as the creature. Human's commitment to Allah will stimulate human's commitment to humans and the universe.

\section{Meaning of Accountability}

Accountability is a fundamental concept of an organization, and is even the main factor to cause some giant companies in the world to collapse, including accounting office Arthur Andersen in Enron and WorldCom because of accountability failure (Frink and Klimoski, 2004). Accountability in the concept of modern entity (entity theory) has not reached the level of stimulating God consciousness, but tends to prioritize mind rationality. This may be observed from the definition by Roberts and Scapens (1985) that accountability is a relationship between giver, beneficiary and other parties regarding something acceptable to common sense. The said relationship is the logical consequence between the agent (management) and the principal (owner) see (Triyuwono and Roekhudin, 2000; Frink and Klimoski, 2004).

Accountability in the definition above will have the implication in the perception of ownership, power and values on which it is based. The power of a modern business entity is at shareholders' egoistic value (Triyuwono, 2016). Accountability under the umbrella of the entity theory only acknowledges relationship between humans and, even narrower, between agent and principal. This accountability lacks of spiritual values, since it negates relationship with God. This will have the implication in the behavior of those carrying the accountability, who also tend to follow egoistic passion. This accountability certainly has the implication in the goal and instrument of business entity that is only material oriented. This is as what Hameed (2001) states, that the use of conventional accounting causes inconsistent and deviating behaviors for Muslim users, since it does not conform to Islamic values and may make the objective of Islamic business entity fail.

The accountability explained above cannot promote the objective of sharia accounting at all, which is able to stimulate and lead human behavior to "God consciousness" (Triyuwono, 2015). The existence of Sharia Accounting needs a concept of accountability which is in line with it, as what Baydoun \& Willett (1997) state that this will bring up a broader concept of accountability than that in Western society. This is positively responded to by Triyuwono (2015), stating that sharia accounting is the instrument of 
accountability to God, mankind, and nature. Therefore, a concept of accountability which may meet the objective of sharia accounting above is needed.

"God consciousness" which is the main objective of sharia accounting is at spiritual reality, which is holy soul (capital spiritual) which is called the most essential of human by Ashmos and Duchon (2000). It is in this spiritual reality where spiritual values lies see (Agustian, 2001) as the ultimate value that may be taken as the base to build scientific knowledge. Therefore, a concept of accountability which is laden with spiritual values is needed, that may bring sharia accounting user to God consciousness.

Sharia Enterprise Theory (SET) has the metaphor of mandate and zakat, prioritizes accountability to God (vertical accountability) which is represented into accountability to humans and nature (Triyuwono, 2015). The concept of SET positions God as the principal (owner) of business entity and stakeholders (humans) as the khalifah (mandate recipient). This means that direct stakeholders and indirect stakeholders has the position of agent pursuant to the mandated function. The concept of vertical accountability may be observed in organization's objective which is oriented to zakat, where balance values are inherent in, namely egoistic-altruistic, material-spiritual, and individual-congregational values (Triyuwono, 2015).

\section{Internalization of Spiritual Values in the Concept of Business Entity's Accountability}

Accountability is influenced by the values internalized in the instrument used to promote the objective of a business entity. Modern accounting is the instrument of accountability to promote the objective of business entity based on the Entity Theory. This concept of accountability has certainly internalized egoistic, materialistic, and utilitarian values (Triyuwono, 2006), making this accountability limited only to one stakeholder, which is owner. Besides, this accountability also has secular value (Hameed, 2001; Mulawarman, et.al, 2007), disregarding spiritual values. The implementation of accountability which is born from the entity theory has evidently failed, as proven by Frink and Klimoski's opinion (2004) that the event of failure of the Arthur Andersen accounting firm in Enron and WorldCom is because of accountability failure.

It is important to internalize spiritual values in a concept of accountability, particularly the itsar (altruistim), volunteerism, willingness, righteousness, honesty, and justice values. Lazar (2004) state that spirituality may free us from material shackle, which may be observed in decision making or through consumers' attitude and behavior. This is confirmed by Ludigdo and Kamayanti (2012) that spirituality is eventually the liberator of anthropocentric capitalism towards humane capitalism. This way, internalization of spiritual values in an instrument is greatly needed, since actually spirituality serves to control materiality.

Internalization of spiritual values in Sharia Enterprise Theory (SET) based accountability is based on the metaphor of mandate and zakat. This accountability has internalized balanced values, namely egoistic-altruistic, material-spiritual, and individual-congregational values (Triyuwono, 2015) as well as justice value (Mulawarman, 2006). This metaphor of zakat is indeed defined in the context of value (Triyuwono, 2011), but it cannot just be separated from definition of zakat in the formal context of Islamic teaching.

Zakat is mandatory and may be enforced on those meeting the nishab and certain requirements, while for those not meeting the nishab and certain requirements, it is not mandatory. The concept of zakat has indeed covered material, psychological, and spiritual values, but it cannot cover what is desired by SET. For example, the distribution of welfare is only limited to eight asnaf, while the stakeholders of SET are quite extensive, covering the whole mankind and nature. Further, the mandatory trait and enforceability of zakat may reduce some spiritual values such as honesty value, righteousness value, volunteerism value and willingness value.

\section{Spiritual Accountability}

Business entity's accountability is to God, humans, and the universe (Triyuwono, 2015; Padmantyo, 2010). Napier (2009) in his writing of accounting history also discusses the concept of accountability, that in religious context, either Islam or Christianity, the main responsibility is to God. Napier (2009) also 
argues that the main accountability to God does not prevent secular accountability to humans (society, investor, and employer) and the nature (others). Therefore, the existence of spiritual accountability is quite important as a more holistic concept of accountability as suggested by Baydoun \& Willett (1997), to promote extensive distribution of welfare.

Spiritual accountability is highly laden with spiritual values as the source of virtue. This concept starts from searching for value added, either material, psychological or spiritual, in the research's case study. Based on the research result, there are informant's expressions or documentation indicating the existence of value added, either material, psychological, or spiritual. First, the non-monetary material values added are in the form of survival of business for twenty five years and good relationship, whether on business motive or otherwise. Second, the psychological value added is in the form of transfer of happiness because of customer's trust. Third, the spiritual value added is in the form of willingness in serving customers and towards employees. The three values added may manifest when they are based on love as the basic spiritual value of material value, psychological value and other spiritual values. Love is a characteristic of soul, which is essentially the love for Allah (Nurbakhsy, 2008).

The three found values added above refer to the concept of sadaqah, which contains the three simultaneously. By context of value, sadaqah contains material (monetary and non-monetary), psychological, and spiritual values. Spiritual values in sadaqah cover itsar (altruistim), righteousness, volunteerism, sincerity, honesty, and justice. When the values are internalized in accountability, the accountability will have a more holistic concept, particularly regarding distribution of welfare to stakeholders. Finally, this accountability is called Spiritual Accountability.

Spiritual Accountability is a commitment to perform accountability to stakeholders (God, humans and nature) based on love spiritual value, either material or immaterial (psychological and spiritual). This spiritual accountability places stakeholders' (human) commitment, especially capital owner and management to be continuously at God consciousness "ESPD". The "spirit" of connectedness with God will always influence each of management's behaviors in managing business entity, which is the representation of accountability (Triyuwono, 2015). The agent-principal relationship is no longer defined as a management-owner relationship of a business entity, but the relationship between khalifah (agent) and Allah (Principal), thus the owner's power will be under Allah's power. Further, business entity which implements spiritual accountability will automatically be oriented to "maximization of sadaqah", thus the instrument used at the instrument of accountability will internalize love value, of which derivatives are in the form of itsar (altruistim), volunteerism, willingness, righteousness, honesty, and justice values.

\section{CONCLUSION}

Based on the findings in the research and discussion previously reviewed, the following conclusions can be drawn. First, Emotional Intelligence has a significant positive effect on ethical judgment among students. Students who can understand, identify and manage their emotions and others' will always direct their actions in a positive direction to maintain good relations between themselves and the people around them. So that the higher the level of Emotional Intelligence of students, the more ethical judgment will be made. Second, religiosity has a significant positive effect on ethical judgment on students. The values of religiosity that are believed by students can direct their thoughts about what is ethical and unethical based on the principles and commands of God Almighty. This also applies when students face ethical dilemma situations, so that the higher the level of student religiosity, the more assertive they will be in making ethical judgments. Thus the results of this study are expected to be used as input for educational institutions, especially at the university level, to provide services and training to accounting students to improve their Emotional Intelligence and religiosity. Besides, companies can also add indicators of Emotional Intelligence and religiosity in recruiting accounting staff and corporate auditors. This can be done as a step to maintain and increase the company's credibility and integrity in the future.

The limitation of this study is that the subjects used in this study are accounting students who still have no experience in the world of work. So there is the possibility that these findings will differ from their actions and decisions when they are faced with ethical dilemma situations in the work environment later. Future studies should use accountants or auditors who have experience in the work environment as 
research subjects. Further research can also add other relevant factors, both internal and external, that influence ethical judgment such as age, gender, moral reasoning, ethical education, ethical climate, and organizational ethical culture.

\section{REFERENCES}

Akers, M. D., \& Porter, G. L. (2003). Your EQ Skills: Got What It Takes? Journal of Accountancy, 195(3), 65-70.

Angelidis, J., \& Ibrahim, N. A. (2011). The Impact of Emotional Intelligence on the Ethical Judgment of Managers. Journal of Business Ethics, 99(1), 111-119. https://doi.org/10.1007/s10551-011-1158-5

Aziz, A., \& Cahyonowati, N. (2015). Pengaruh Ethical Ideology Terhadap Ethical Judgements Pada Mahasiswa Akuntansi [The Influence of Ethical Ideology to Ethical Judgements in the Accounting Students]. Diponegoro Journal of Accounting, 4(3), 437-444.

Chan, S. Y. S., \& Leung, P. (2006). The Effects of Accounting Students' Ethical Reasoning and Personal Factors on Their Ethical Sensitivity. Managerial Auditing Journal, 21(4), 436-457. https://doi.org/10.1108/02686900610661432

Deshpande, S. P., \& Joseph, J. (2009). Impact of Emotional Intelligence, Ethical Climate, and Behavior of Peers on Ethical Behavior of Nurses. Journal of Business Ethics, 85(3), 403-410. https://doi.org/10.1007/s10551-008-9779-Z

Dewi, P. E. D. M., Martadinata, I. P. H., \& Diputra, I. B. R. P. (2019). Analisis Hubungan Kecerdasan Emosional Dan Love of Money Terhadap Perilaku Etis Mahasiswa (Studi Empiris Pada Mahasiswa S1 Akuntansi Universitas Pendidikan Ganesha) [An Analysis on the Relationship between Emotional Intelligence and Love of Money to the Students' Ethical Behaviors]. Jurnal Ilmiah Akuntansi [Acounting Scientific Journal], 3(2), 154-170. https://doi.org/10.23887/jia.v3i2.16638

Economica. (2019). PwC Italy Partner Named in BT Criminal Investigation. (Online), (https://economia.icaew.com/news/february-2019/pwc-italy-partner-named-in-bt-criminalinvestigation), accessed on 4 November 2019

Emerson, T. L. N., Conroy, S. J., \& Stanley, C. W. (2007). Ethical attitudes of accountants: Recent evidence from a practitioners' survey. Journal of Business Ethics, 71(1), 73-87. https://doi.org/10.1007/s10551-006-9125-2

Fadhilah, A. N. (2019). Analisis Pengaruh Kompetensi Moral, Tingkat Religiusitas, dan Efikasi Diri Terhadap Academic Dishonesty [An Analysis on the Influence of Morality Competence, Religiosity Level and Self-Efficacy to the Academic Dishonesty]. Unpublished Undergraduate Thesis. Malang: Faculty of Economics and Business, Universitas Negeri Malang

Helmy, H. (2018). The Influence of Ethical Orientation, Gender, and Religiosity on Ethical Judgment Accounting Students. Advances in Economics, Business and Management Research, 57, 50-56. https://doi.org/10.2991/piceeba-18.2018.78

Hunt, S. D., \& Vitell, S. (1986). A General Theory of Marketing Ethics. Journal of Macromarketing, 6, 516.

Ismail, S. (2015). Influence of Emotional Intelligence, Ethical Climates, and Corporate Ethical Values on Ethical Judgment of Malaysian Auditors. Asian Journal of Business Ethics, 4(2), 147-162. https://doi.org/10.1007/s13520-015-0047-x

Ismail, S., \& Rasheed, Z. (2019). Influence of Ethical Ideology and Emotional Intelligence on The Ethical Judgement of Future Accountants in Malaysia. Meditari Accountancy Research. https://doi.org/10.1108/medar-04-2018-0326

Jaafar, J., Kolodinsky, P., McCarthy, S., \& Schroder, V. (2004). The impact of cultural norms and values 
of the moral judgment of Malay and American adolescents: A brief report. Papers from the International Association for Cross-Cultural Psychology Conference, 399-414.

Keller, A. C., Smith, K. T., \& Smith, L. M. (2007). Do Gender, Educational Level, Religiosity, and Work Experience Affect The Ethical Decision-Making of U.S. Accountants? Critical Perspectives on Accounting, 18(3), 299-314. https://doi.org/10.1016/j.cpa.2006.01.006

Kohlberg, L. (1969). Stage And Squence: The Cognitive-Developmental Approach To Socialization. 347480.

Kohlberg, L. (1984). Essays on moral development: The psychology of moral development (Vol. 2). New York: Harper \& Row

McDaniel, S. W., \& Burnett, J. J. (1990). Consumer Religiosity and Retail Store Evaluative Criteria. Journal of the Academy of Marketing Science, 18(2), 101-112. https://doi.org/10.1007/BF02726426

Mesmer-Magnus, J., Viswesvaran, C., Joseph, J., \& Deshpande, S. P. (2008). The Role of Emotional Intelligence In Integrity and Ethics Perceptions. Research on Emotion in Organizations, 4(8), 225239. https://doi.org/10.1016/S1746-9791(08)04010-8

Nasikhah, D., \& Prihastuti. (2013). Hubungan antara Tingkat Religiusitas dengan Perilaku Kenakalan Remaja pada Masa Remaja Awal [The Relationship between Religiousity Level and Juvenile Deiquency Behavior at the Beginning of Addolescence]. Jurnal Psikologi Pendidikan Dan Perkembangan [Journal of Psychological Education and Development], 2(2), 69-72.

Nurhayati, S. (2006). Telaah Kritis Terhadap Teori Perkembangan Moral Lawrence Kohlberg [A Critical Study on the Lawrence Kohlberg's Morality Development Theory]. Paradigma: Jurnal Psikologi Pendidikan Dan Konseling [Paradigma Journal of Psychological Education and Counseling], (2), 93-104.

Pamungkas, I. D. (2014). Pengaruh Religiusitas dan Rasionalisasi dalam Mencegah dan Mendeteksi Kecenderungan Kecurangan Akuntansi [The Influence of Religiousity and Rationalization in Preventing and Detecting the Accounting Fraud Tendency]. Jurnal Ekonomi Dan Bisnis [Journal of Economics and Business], 15(2), 48-59.

Rahmawati, A. (2019). Pengaruh Fraud Diamond, Reigiusitas, dan Self Efficacy Terhadap Academic Fraud [The Influence of Fraud Diamond, Religiosity, and Self Efficacy on Academic Fraud]. Unpublished Undergraduate Thesis. Malang: Faculty of Economics and Business, Universitas Negeri Malang

Resty, N. N. H. (2018). Pengaruh Religiusitas dan Gender Terhadap Penilaian Etis (Ethical Judgement) Mahasiswa Akuntansi Minangkabau [The Influence of Religiousity on Ethical Judgment of the Accounting Students from Minangkabau]. Jurnal EcoGen [EcoGen Journal], 1(4), 858-869.

Reuters. (2019). Exclusive: BT Executives Knew of Accounting Fraud in Italy Unit - Prosecutors. (Online). (https://www.reuters.com/article/us-bt-italy-exclusive/exclusive-bt-executives-knew-ofaccounting-fraud-in-italy-unit-prosecutors-idUSKCN1Q216M), accessed 4 November 2019

Sagoro, E. M. (2013). Pensinergian Mahasiswa, Dosen, dan Lembaga Dalam Pencegahan Kecurangan Akademik Mahasiswa Akuntansi [Sinergizing the Students,Lecturers, and Institutions in Preventing from the Academic Fraud Made by the Accounting Students]. Jurnal Pendidikan Akuntansi Indonesia [Journal of Indonesian Accounting Education], 11(2), 54-67. https://doi.org/10.21831/jpai.v11i2.1691

Salovey, P., \& Mayer, J. D. (1990). Emotional Intelligence. Imagination, Cognition and Personality, 9(3), 185-211. https://doi.org/10.2190/DUGG-P24E-52WK-6CDG

Suliani, M., \& Marsono. (2010). Pengaruh Pertimbangan Etis, Perilaku Machiavelian, dan Gender dalam 
Pembuatan Keputusan Etis Mahasiswa S1 Akuntansi [The Influence of Ethical Consideration, Machiavelian Behavior, and Gender on the Ethical Decision Making Committed by the Accounting Students at Bachelor Degree]. Jurnal Akuntansi Dan Auditing [Journal of Accounting and Auditing], 7(1), 62-79. https://doi.org/10.14710/jaa.v7i1.4677

Walker, A. G., Smither, J. W., \& DeBode, J. (2012). The Effects of Religiosity on Ethical Judgments. Journal of Business Ethics, 106(4), 437-452. https://doi.org/10.1007/s10551-011-1009-4

Weaver, G. R., \& Agle, B. R. (2002). Religiosity and Ethical Behavior in Organizations: A Symbolic Interactionist Perspective. Academy of Management Review, 27(1), 77-97. https://doi.org/10.5465/AMR.2002.5922390

Wong, C., \& Law, K. S. (2002). The Effects of Leader and Follower Emotional Intelligence on Performance and Attitude: An Exploratory Study. The Leadership Quarterly, 13, 243-274. 